\title{
PENGARUH PEMANFAATAN ALAT PERAGA BERBASIS KEARIFAN LOKAL TERHADAP PENINGKATAN HASIL BELAJAR FISIKA PADA SISWA KELAS VIII DI MTS NURUL IMAN NW KEMBANG KERANG LOMBOK TENGAH TAHUN PELAJARAN 2017/2018
}

\author{
Islahudin $^{1 *}$, Ni Wayan Sri Darmayanti², Zulkarnain ${ }^{3}$ \\ ${ }^{1 * 2283}$ Dosen Progran Studi Pendidikan Fisika Universitas Muhammadiyah Mataram \\ Corresponding author : \\ E-mail : (islahudin.ntb@gmail.com)
}

Diterima 25 Oktober 2017, Disetujui 8 November 2017

\begin{abstract}
ABSTRAK
Penelitian yang telah dilakukan ini tentang pengaruh pemanfaatan alat peraga berbasis kearifan lokal terhadap peningkatan hasil belajar fisika pada siswa kelas VIII di MTs Nurul Iman NW Kembang Kerang Lombok Tengah Tahun Pelajaran 2017/2018. Penelitian ini bertujuan untuk mengetahui pengaruh pemanfaatan alat peraga berbasis kearifan lokal terhadap peningkatan hasil belajar fisika pada siswa kelas VIII di MTs Nurul Iman NW Kembang Kerang Lombok Tengah Tahun Pelajaran 2017/2018. Metode yang digunakan dalam penelitian ini adalah Pre Experimental Design dengan model One-Group PretestPosttes Design. Teknik analisis data menggunakan pre test dan post test menggunakan rumus uji pengaruh atau uji $t$, sebelum data dianalisis menggunakan uji $t$ terlebih dahulu dilakukan uji normalitas dan homogenitas. Untuk mengetahui apakah terdapat perbedaan yang signifikan terhadap analisis data dengan menggunakan uji t. Jika t hitung $<\mathrm{t}$ tabel maka perbedaan test tidak signifikan atau bisa dikatakan tidak memiliki pengaruh, sebaliknya jika $t_{\text {hitung }}>\mathrm{t}_{\text {tabel }}$ maka perbedaan tes signifikan atau bisa dikatakan memiliki pengaruh. Hasil perhitungan menunjukkan bahwa nilai thitung $(6,11)$ lebih besar dari tabel $(2,04)$. Berdasarkan hasil penelitian menunjukan bahwa terdapat pengaruh yang signifikan penggunaan alat peraga alam terhadap peningkatan hasil belajar fisika pada siswa kelas VIII di MTs Nurul Iman NW Kembang Kerang Lombok Tengah Tahun Pelajaran 2017/2018.
\end{abstract}

Kata Kunci: Pemanfaatan, Alat Peraga, Kearifan Lokal, Hasil Belajar, MTs Nurul Iman NW.

\section{PENDAHULUAN}

Sains adalah hasil kegiatan
manusia berupa pengetahuan, pengalaman yang lahir melalui proses ilmiah. Tujuan pembelajaran sains khususnya fisika adalah pembelajaran yang diarahkan pada kegiatan-kegiatan yang mendorong siswa belajar aktif baik fisik, mental intelektual dan sosial untuk memahami konsep fisika.

IImu fisika sering dirasakan sebagai materi yang sukar untuk dipahami oleh siswa. Berbagai penelitian telah dilakukan oleh para pakar pendidikan untuk memudahkan dalam pemahaman materi fisika terutama dalam mengerjakan soalsoal fisika. Salah satu penelitian yang paling menarik dikembangkan sekarang ini adalah media animasi. Peningkatan hasil dan motivasi belajar terhadap materi fisika telah diperoleh secara signifikan oleh para siswa menggunakan media animasi. Media animasi pada dasarnya merupakan kombinasi antara gambar dan grafik yang didesain sedemikian rupa sehingga mampu membuat para peserta didik tertarik untuk melihatnya. Oleh karena itu, sangat jelas terlihat bahwa gambar dan grafik sangat membantu untuk memudahkan proses pemahaman materi fisika.

Pelajaran fisika harus dipahami secara universal/secara menyuluruh dengan pemahaman konsep yang benar maka pelajaran fisika sangat mudah untuk dipelajari. Memahami konsep fisika yang benar adalah mengetahui apa kegunaan dan relevansinya dalam kehidupan seharihari. Pada Sekolah Menengah Pertama (SMP) pelajaran fisika sudah dikenalkan dan diajarkan kepada anak kelas VII,VIII dan IX.

Pelajaran fisika umunya dianggap pelajaran yang sulit, ini dilihat dari hasil tes ujian semester di MTs Nurul Iman NW dengan rata-rata 5,21 dengan Standar Ketuntasan Minimal (SKM) 6,50. Menurut peneliti hal ini di sebabkan karena pelajaran fisika disampaikan dengan cara konvensional misalnya dengan metode 
ceramah sehingga pelajaran fisika kurang diminati.

Pada observasi yang dilakukan peneliti di MTs Nurul Iman NW, pelajaran fisika umunya disampaikan dengan metode ceramah, hal ini disebabkan tidak ada ruang laboraturium fisika dan media pendukung penunjang kegiatan belajar mengajar khusunya pada mata pelajaran fisika.

Media pengajaran sangat penting sebab media adalah alat bantu mentranfer ilmu untuk meningkatkan hasil belajar yang dicapai. Alasan media pembelajaran dapat meningkatkan hasil belajar antara lain : (1) Pengajaran akan lebih menarik perhatian siswa sehingga dapat menumbuhkan motivasi belajar; (2) Bahan pengajaran akan lebih jelas maknanya sehingga dapat lebih dipahami oleh para siswa, dan memungkinkan siswa menguasai tujuan pengajaran lebih baik; (3) Metode mengajar akan lebih bervariasi, tidak semata-mata komunikasi verbal melalui penuturan kata-kata oleh guru, sehingga siswa tidak bosan dan guru tidak kehabisan tenaga, apalagi bila guru mengajar untuk setiap jam pelajaran; (4) Siswa lebih banyak melakukan kegiatan belajar, sebab tidak hanya mendengarkan uraian guru, tetapi juga aktivitas lain seperti mengamati, melakukan, mendemonstrasikan dan lain-lain.

Dalam pembelajaran fisika, media adalah bagian penting sebagai penunjang motivasi dan peningkatan hasil belajar. Beberapa contoh media pembelajaran fisika antara lain ; (1) Jangka Sorong. Jangka sorong digunakan untuk mengukur deminsi luar atau deminsi dalam suatu benda; (2) Mesin hedrolik. Mesin ini biasa kita temukan di bengkel mobil atau tempat pencucian mobil fungsinya untuk mengangkat mobil.

Media pembelajaran fisika sangat beragam, seperti contoh di atas. media tersebut diperoleh dengan membeli atau membuat sendiri. Kalau membeli tentu biayanya sangat mahal sedangkan membuat sendiri, biaya menjadi terjangkau yaitu dengan barang-barang bekas atau jenis lainnya.

Berdasarkan latar belakang di atas peneliti tertarik untuk melakukan penelitian tentang "Pengaruh Penggunaan Alat Peraga Berbasis Kearifan Lokal Terhadap Peningkatan Hasil Belajar Fisika Pada Siswa Kelas VIII di MTs Nurul Iman NW Kembang Kerang Lombok Tengah Tahun Pelajaran 2017/2018".

\section{METODE PENELITIAN \\ Metode Penelitian}

Metode yang digunakan dalam penelitian ini adalah metode Preeksperimen. Menurut Sugiono (2010:109) bahwa penelitian Pre-eksperimen hasilnya merupakan variabel dependen bukan semata-mata dipengaruhi oleh variable independen. Hal ini terjadi karena tidak adanya variabel kontrol, dan sampel tidak dipilih secara random. Desain penelitian yang digunakan dalam penelitian ini adalah one group pretest-posttest design. Dalam desain ini, sebelum perlakuan diberikan terlebih dahulu sampel diberi pretest (tes awal) dan diakhir pembelajaran diberi posttest (tes akhir). Desain ini digunakan sesuai dengan tujuan yang hendak dicapai yaitu ingin mengetahui peningkatan hasil belajar siswa setelah diberikan pembelajaran menggunakan alat peraga alam. Berikut tabel desain penelitian one group pretestposttest design.

Tabel 1. Desain penelitian one group pretest-posttest design

\begin{tabular}{|c|c|c|}
\hline Pretest & Treatment & Posttest \\
\hline $\mathbf{O}_{1}$ & $\mathbf{X}$ & $\mathbf{O}_{2}$ \\
\hline
\end{tabular}

Keterangan:

(Sugiono, 2008:111)

$\mathrm{O}_{1}$ : tes awal sebelum perlakuan diberikan

$\mathrm{O}_{2}$ : tes akhir setelah perlakuan diberikan $X$ : perlakuan terhadap kelompok eksperimen yaitu dengan cara memberikan pembelajaran menggunakan alat peraga berbasis kearifan lokal.

\section{Tempat dan Waktu Penelitian Tempat Penelitian}

Penelitian ini dilaksanakan di MTs Nurul Iman NW Kembang Kerang di Desa Aik Dareq Kecamatan Batukliang Kabupaten Lombok Tengah Tahun Pelajaran 2017/2018.

\section{Waktu Penelitian}

Penelitian ini dilaksanakan selama 3 bulan yaitu bulan oktober sampai Desember 2017.

\section{Populasi dan Sampel Penelitian}

Populasi penelitian adalah siswa MTs Nurul Iman NW Kembang Kerang. Adapun sampel pada penelitian ini adalah siswa kelas VIII MTs Nurul Iman NW Kembang Kerang Tahun Pelajaran $2017 / 2018$. 


\section{Variabel Penelitian}

Menurut Sugiyono "variabel penelitian adalah suatu atribut atau sifat atau nilai dari orang, objek atau kegiatan yang mempunyai variasi tertentu yang ditetapkan oleh peneliti untuk dipelajari dan kemudian ditarik kesimpulan".

\section{Variabel bebas (Independent variable)}

Variabel bebas adalah variabel yang mempengaruhi atau yang menjadi sebab perubahan atau timbulnya variabel terikat (independent variable). Variabel bebas dalam penelitian ini adalah penggunaan alat peraga alam terhadap peningkatan hasil belajar fisika pada siswa kelas VIII di MTs Nurul Iman NW Kembang Kerang Lombok Tengah Tahun Pelajaran 2017/2018 pada materi Getaran dan Gelombang.

\section{Variabel terikat (Dependent variable)}

Variabel terikat merupakan variabel yang dipengaruhi atau yang menjadi akibat karena adanya variabel bebas. Sedangkan variabel terikat dalam penelitian ini adalah peningkatan hasil belajar fisika siswa kelas VIII di MTs Nurul Iman NW Kembang Kerang Lombok Tengah Tahun Pelajaran 2017/2018 pada materi Hukum Newton.

\section{Prosedur penelitian.}

Penelitian ini meliputi tiga tahap yaitu tahap persiapan penelitian, tahap pelaksanaan penelitian, dan tahap akhir penelitian. Adapun alur penelitian tampak sebagai berikut.

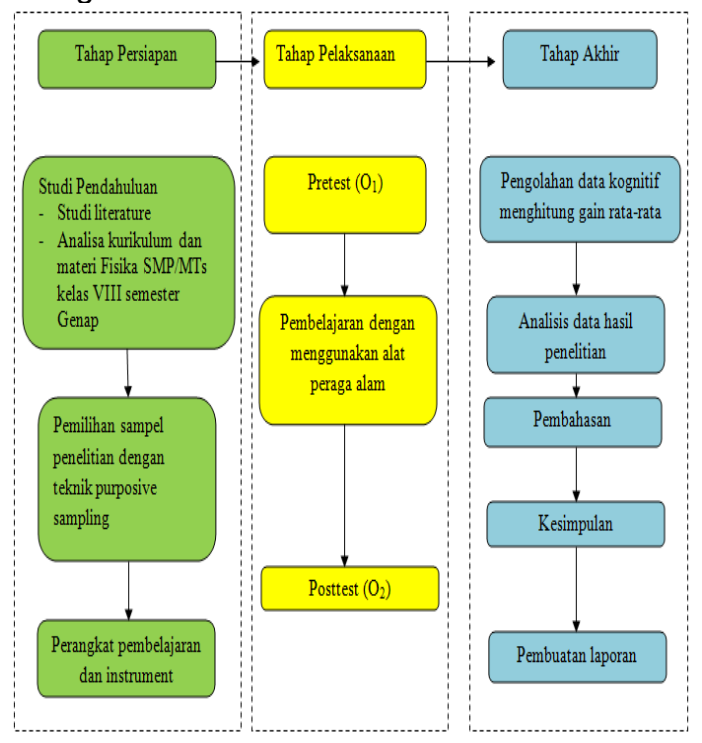

Gambar 1. Alur penelitian
Integrasi Kearifan Lokal Suku Sasak dengan materi Hukum Newton

Adapun bentuk integrasi kearifan lokal Suku Sasak dengan materi hukum newton tampak pada Tabel 2 berikut.

Tabel 2. Integrasi kearifan lokal daerah suku sasak dengan materi Hukum Newton

\begin{tabular}{lll} 
& Kearifan Lokal & \multicolumn{1}{c}{$\begin{array}{c}\text { Bentuk } \\
\text { Integrasi }\end{array}$} \\
\hline 1 & $\begin{array}{l}\text { Cidomo ditarik oleh } \\
\text { kuda Di Lombok }\end{array}$ & $\begin{array}{l}\text { Menjelaskan } \\
\text { pengertian } \\
\text { Gaya }\end{array}$ \\
\hline 2 & $\begin{array}{l}\text { Permainan tarik } \\
\text { tambang }\end{array}$ & $\begin{array}{l}\text { Menjelaskan } \\
\text { aplikasi gaya }\end{array}$ \\
\hline 3 & Permainan tolak & $\begin{array}{l}\text { Menjelaskan } \\
\text { tentang } \\
\text { peluru }\end{array}$ \\
& aplikasi gaya \\
\hline
\end{tabular}

\section{Teknik Pengumpulan Data dan Analisis} Data

Untuk memperoleh data hasil belajar siswa maka perlu dibuat instrumen penelitian. Adapun langkah-langkah penyusunan instrumen penelitian sebagai berikut :

\section{Teknik Pengumpulan Data}

Pengumpulan data dilakukan dengan menggunakan intrumen tes. Instrumen yang digunakan dalam penelitian ini adalah berbentuk tes pilihan ganda. Tes pilihan ganda (Multiple Choice Test) yaitu tes dimana setiap butir soalnya memiliki jumlah alternatif jawaban lebih dari satu. Biasanya terdapat dua sampai lima alternatif jawaban yang disuguhkan dan jumlah alternatif jawaban tersebut tidak boleh terlalu banyak karena akan sangat membingungkan dan juga sangat menyulitkan penyusunan butir soal. Instrumen penelitian ini untuk mengukur daerah kognitif pada tingkat pemahaman. Menurut Nurkancana, dkk (1983:13) pemahaman (comprehensif) adalah kemampuan untuk memahami segala pengetahuan yang diajarkan seperti kemampuan untuk mengungkapkan dengan struktur kalimat lain, membandingkan, menafsirkan dan sebagainya.

Soal yang digunakan pada tes awal sama dengan soal yang digunakan pada tes akhir. Hal ini dimaksudkan supaya tidak ada pengaruh perbedaan instrument terhadap perubahan hasil belajar fisika yang terjadi. Instumen tes yang akan digunakan dalam penelitian ini sebanyak 30 soal pilihan ganda. 


\section{Teknik Uji Coba Instrumen}

Sebelum instrumen digunakan dalam penelitian, terlebih dahulu instrumen akan diujicobakan pada kelas IX MTs Nurul Iman NW Kembang Kerang yang telah mendapatkan pembelajaran pada pokok bahasan getaran dan gelombang. Instrument tersebut setelah diujicobakan kemudian diolah dan dianalisis. Adapun analisis-analisis yang digunakan untuk mengetahui layak atau tidaknya instrument tes penelitian digunakan yaitu uji validitas, uji reliabilitas, uji taraf kesukaran soal, dan uji daya pembeda soal.

\section{Teknik Analisis Data}

Analisis data dilakukan dengan membandingkan nilai rata-rata pre-test dan post-test kelas eksperimen mata pelajaran Fisika pada siswa kelas VIII di MTs Nurul Iman NW Kembang Kerang Lombok Tengah Tahun Pelajaran 2017/2018. Analisis ini menggunakan uji satu sampel untuk rata-rata (one sample $t$ test). Dengan uji tersebut akan diketahui apakah ada pengaruh antara nilai rata-rata pre-test dan post-test kelas eksperimen.

\section{Analisis Data Tahap Awal}

Sebelum dilakukan uji one sample t test, terlebih dahulu diuji normalitas untuk mengetahui apakah kelas eksperimen berdistribusi normal atau tidak. Jika kelas tersebut berdistribusi normal, maka statistik yang digunakan adalah statistik parameter. Sedangkan jika menggunakan statistik nonparameter, maka kelas tersebut tidak harus berdistribusi normal. Metode untuk menganalisis data adalah sebagai berikut:

\section{a. Uji Normalitas}

Uji normalitas digunakan untuk mengolah data nilai pre-test dalam menentukan apakah kelas yang telah diuji berdistribusi normal atau tidak. Rumus pengujian ini dikenal dengan Chi Kuadrat. Rumus yang digunakan adalah:

$$
x^{2}=\sum_{i=1}^{k} \frac{\left(f_{O}-f_{h}\right)^{2}}{f h}
$$

Keterangan:

$$
\begin{aligned}
& \chi^{2}=\text { chi kuadrat } \\
& f_{o}=\text { frekuensi yang diobservasi } \\
& f_{h}=\text { frekuensi yang diharapkan. }
\end{aligned}
$$$$
\text { Kriteria: Jika } X^{2} \text { hitung } \leq X^{2} \text { tabel dengan }
$$

$\mathrm{dk}=\mathrm{k}-3$ dan $\alpha=5 \%$ maka data berdistribusi normal (Arikunto, 2006: 290)

\section{Analisis Data Tahap Akhir}

Metode untuk menganalisis data nilai akhir setelah diberi perlakuan adalah sebagai berikut:

\section{a. Uji Normalitas}

Uji normalitas digunakan untuk mengolah data nilai post-test dalam menentukan apakah kelas yang telah diuji berdistribusi normal atau tidak. Untuk langkah-langkah pengujian normalitas data tahap akhir sama dengan langkahlangkah uji normalitas pada analisis data tahap awal.

\section{b. Uji Homogenitas}

Uji homogenitas varians dicari dengan menggunakan rumus uji-F yaitu dengan rumus:

$$
F=\frac{\text { Varians Terbesar }}{\text { Varians Terkecil }}
$$

Kriteria pengujian: Jika $F_{\text {hitung }}>F_{\text {tabelberarti tidak homogen dan jika }}$ $F_{\text {hitung }}<F_{\text {tabel }}$ berarti homogen pada taraf signifikan 5\% (Sugiyono, 2012:276).

\section{c. Uji Hipotesis}

Uji perbedaan dua rata-rata digunakan untuk mengetahui pengaruh hasil pre-test sebelum diberikan perlakuan (treatment) dan hasil post-test sesudah diberi perlakuan (treatment). Untuk mengetahui perbedaan dua rata-rata ini menggunakan uji satu pihak (uji t) yaitu uji pihak kiri. Hipotesis yang digunakan adalah sebagai berikut:

$$
\begin{aligned}
& \mathrm{H}_{0}: \mu_{1} \geq \mu_{2} \\
& \mathrm{H}_{1}: \mu_{1}<\mu_{2}
\end{aligned}
$$

Keterangan:

$$
\begin{aligned}
& \mu_{1}=\text { rata-rata nilai post-test } \\
& \mu_{2}=\text { rata-rata nilai pre-test }
\end{aligned}
$$

Untuk menguji hipotesis di atas digunakan statistik uji $t$ sebagai berikut:

$$
t=\frac{\overline{x_{1}}-\overline{x_{2}}}{s \sqrt{\frac{1}{n_{1}}+\frac{1}{n_{2}}}}
$$

Di mana:

$$
s=\sqrt{\frac{(n-1) s_{1}^{2}+(n-1) s_{1}^{2}}{n_{1}+n_{2}-2}}
$$

Keterangan:

$\overline{x_{1}} \quad=$ Rata-rata post-test

$\overline{x_{2}}=$ Rata-rata pre-test

$\mathrm{n}_{1}=$ Jumlah siswa pada saat post-test

$\mathrm{n}_{2}=$ Jumlah siswa pada saat pre-test

$s_{1}^{2}=$ Standar deviasi post-test 
$s_{2}^{2}=$ Standar deviasi pre-test

$s \quad=$ Simpangan baku

Jika anggota sampel $\mathrm{n}_{1}$ dan $\mathrm{n}_{2}$ dan varians homogen, maka dapat digunakan dengan ketentuan jika thitung $<t_{\text {tabel }}$ maka hipotesis $\mathrm{H}_{0}$ diterima dan $\mathrm{Ha}$ ditolak dan $t_{\text {hitung }}>t_{\text {tabel }}$ maka hipotesis nol $(\mathrm{Ho})$ ditolak dan (Ha) diterima (Sugiyono, 2012: 273274).

\section{d. Uji N-gain}

Untuk mengetahui peningkatan hasil belajar fisika menggunakan alat peraga alam dilakukan melalui analisis terhadap skor gain ternormalisasi < $\mathrm{g}>$ yang dikemukakan Hake (1998), dalam Suparno, Paul, 2005) dengan rumus:

$$
<g>=\frac{T_{2}-T_{1}}{T_{\text {maks }}-T_{1}}
$$

Dengan $<\mathrm{g}>$ yaitu skor gain ternormalisasi, $\mathrm{T}_{2}$ adalah skor posttest, $\mathrm{T}_{1}$ yaitu skor pretest. Pembelajaran yang baik bila gain skor ternormalisai lebih besar dari 0,4. Menurut Hake (1998) hasil skor gain ternormalisasi dibagi ke dalam tiga kategori yang tampak pada Tabel 3 berikut.

Tabel 3. Kriteria Gain Ternormalisasi

\begin{tabular}{|l|l|}
\hline \multicolumn{1}{|c|}{ Persentase } & \multicolumn{1}{c|}{ Klasifikasi } \\
\hline $0,00<\mathrm{g}<0,30$ & Rendah \\
\hline $0,30 \leq \mathrm{g} \leq 0,7$ & Sedang \\
\hline $0,70<\mathrm{g}<1,00$ & Tinggi \\
\hline
\end{tabular}

Hasil penelitian

Hasil Studi Pendahuluan

Penelitian eksperimen ini telah dilaksanakan pada Desember 2017 sampai bulan Januari 2018 di MTs Nurul Iman NW Kembang Kerang Lombok Tengah Tahun Pelajaran 2017/2018. Penelitian ini dilakukan dalam 4 kali pertemuan, dengan rincian 2 kali pertemuan dalam 4 jam pelajaran untuk pre-test dan post-test instrumen soal, selanjutnya 2 kali pertemuan digunakan untuk kegiatan pelajaran.

Hasil observasi awal di MTs Nurul Iman NW Kembang Kerang Lombok Tengah menunjukan bahwa hasil belajar siswa fisika masihdi bawah KKM. Hal ini disebabkan karena sebagian besar waktu belajar siswa dihabiskan untuk mendengarkan penjelasan dari guru, menghafal materi dan mencatat materi sehingga siswa kurang aktif dan kurang menguasai konsep-konsep dasar fisika, ini dapat dilihat dari siswa kurang aktif dalam bertanya, apabila diberikan pertanyaan hanya sedikit siswa yang memberikan jawaban dan terbatas pada siswa tertentu dan proses pembelajaran didominasi oleh guru.

Pembelajaran yang berkualitas tidak hanya ditentukan oleh kurikulum yang baru, kepribadian guru yang simpatik, wawasan pengetahuan yang luas, tetapi ditentukan pula oleh metode atau media pembelajaran yang digunakan pada saat pembelajaran yang harus dikembangkan oleh guru. Metode pembelajaran yang sering digunakan siswa MTs Nurul Iman NW Kembang Kerang Lombok Tengah adalah metode ceramah sehingga siswa kurang aktif dan kurang menguasai konsep-konsep dasar fisika.

\section{Hasil Uji Coba Instrumen Uji Validitas Instrumen}

Sebelum tes diberikan kepada siswa, terlebih dahulu dilakukan uji validitas terhadap soal yang akan diuji untuk mengetahui apakah soal-soal tersebut layak untuk digunakan dalam penelitian. Dari hasil uji coba instrumen yang dilakukan pada kelas IX MTs Nurul Iman NW Kembang Kerang Lombok Tengah dengan jumlah siswa sebanyak 24 orang. Dari 30 soal pre-test dan post-test yang diuji cobakan diperoleh 20 soal yang valid dan 10 soal invalid. Untuk $\mathrm{N}=24$ dengan taraf signifikan 5\%, maka diperoleh $r_{\text {tabel }}=0,404$ sehingga dapat ditentukan valid tidaknya soal tersebut.

\section{Uji Reabilitas Instrumen}

Uji coba reliabilitas dilakukan pada 30 soal dengan menggunakan rumus KR20 diperoleh nilai $r_{11}$ sebesar 0,930 dan nilai $r_{\text {tabel }}$ untuk taraf signifikan $5 \%$ dengan $\mathrm{N}=24$ sehingga diperoleh nilai 0,404. Oleh karena itu rhitung lebih besar dari pada $r_{\text {tabel }}(0,930>0,404)$. Maka instrumen penelitian ini memiliki tingkat reliabilitas yang kuat/tinggi.

\section{Uji Tingkat Kesukaran Butir Soal}

Uji tingkat kesukaran soal dimaksudkan untuk mengetahui tingkat perbedaan soal yang diberikan kepada siswa. Berdasarka hasil uji tingkat kesukaran soal, diketahui bahwa soal berkriteria sukar sebanyak 4 soal karena berada pada rentang $0,00-0,30$, soal yang berkriteria sedang sebanyak 21 karena berada pada rentang 0,31 - 0,70, sedangkan soal yang berkriteriamudah sebanyak 5 soal karena berada pada rentang 0,71-1,00.

\section{Uji Daya Beda Soal}

Berdasarkan hasil uji daya beda soal, maka dapat disimpulkan bahwa soal yang memiliki daya beda jelek sebanyak 9 
soal karena berada pada rentang 0,00 0,20 , soal yang memiliki daya beda cukup berada sebanyak 9 karena berada pada rentang 0,21 - 0,40 dan soal yang memiliki daya beda baik sebanyak 12 soal karena berada pada rentang $0,41-0,70$.

Hasil Penelitian

Penelitian ini bertujuan untuk mengetahui pengaruh pemanfaatan alat peraga berbasis kearifan lokal terhadap peningkatan hasil belajar fisika pada siswa kelas VIII di MTs Nurul Iman NW Kembang Kerang Lombok Tengah Tahun Pelajaran 2017/2018. Adapun data hasil penelitian yang sudah dilakukan tampak berdasarkan hasil perhitungan statistik sebagai berikut.

Tabel 4. Rangkuman Nilai Pre-Test dan Post-Test kelas Eksperimen

\begin{tabular}{lcccc}
\hline & $N$ & Mean & Min & Maks \\
\hline $\begin{array}{l}\text { Pre- } \\
\text { test }\end{array}$ & 31 & 53,67 & 33 & 75 \\
\hline $\begin{array}{l}\text { Post- } \\
\text { test }\end{array}$ & 31 & 60,56 & 41 & 81 \\
\hline
\end{tabular}

\section{Pembahasan}

Pada saat melakukan test pertama (pretest) dalam penelitian ini didapat hasil mean atau rata-rata yaitu 53,67 dengan nilai terendah yang diperoleh siswa adalah 33 dan nilai tertinggi yang diperoleh siswa adalah 75. Berdasarkan analisis penilaian maka nilai yang diperoleh siswa kurang maksimal, penyebab kurang maksimal nilai yang diperoleh siswa karena adanya siswa kurang memahami materi getaran dan gelombang akibat pembelajaran yang selalu $98 \%$ menggunakan metode ceramah. Namun setelah adanya perlakuan (treatment) maka hasil post test yang diperoleh untuk mean yaitu 60,56 sedangkan nilai terendah yang diperoleh siswa yaitu 41 dan nilai tertinggi adalah 81 . Berdasarkan hasil rata-rata yang diperoleh testee diperoleh bahwa terjadi peningkatan setelah dilakukan perlakuan (treatment) terhadap hasil belajar fisika pada siswa kelas VIII di MTs Nurul Iman NW Kembang Kerang Lombok Tengah Tahun Pelajaran 2017/2018 pada materi Hukum Newton. Adanya peningkatan hasil belajar tersebut sangat berdampak akibat beberapa faktor berikut yaitu 1) pemahaman siswa semakin meningkat karena adanya pemanfaatan alat peraga dalam pembelajaran, 2) siswa semakin memiliki motivasi belajar yang semakin meningkat setelah pemanfaatan alat peraga dalam proses pembejalaran, dan 3) setiap tugas yang diberikan oleh guru selalu dikerjakan secara kelompok dan selalu didiskusikan dengan guru. Sebelum melakukan uji pengaruh terlebih dahulu data yang ada di uji menggunakan uji normalitas, adapun hasil normalitas menunjukan bahwa untuk signifikan Pretes adalah $x^{2}$ hitung $=6,234$ sedangkan signifikan posttes adalah $x^{2}$ hitung $=4,324$ artinya kedua hasil data tersebut lebih besar dari pada $x^{2}$ tabel $=11,07$. Menurut Priyanto (2010:71) menyatakan " Data dinyatakan berdistribusi normal jika signifikansi lebih besar dari 0,05" sehingga data tersebut dinyatakan normal. Adapun keterangan hasil uji normalitas dapat dijelaskan sebagai berikut:

Tabel 5. Hasil Perhitungan Uji Normalitas

\begin{tabular}{lll}
\hline & \multicolumn{1}{c}{ Signifikansi } & Keterangan \\
\hline Pre- & $\left(x^{2}\right.$ hitung $=6,234$ & Normal \\
test & )$<\left(x^{2}\right.$ tabel $=$ \\
& $11,07)$ & \\
\hline Post- & $\left(x^{2}\right.$ hitung $=4,324$ & Normal \\
test & )$<\left(x^{2}\right.$ tabel $=$ & \\
& $11,07)$ & \\
\hline
\end{tabular}

Setelah melakukan uji normalitas maka dilanjutkan dengan uji homogenitas, berdasarkan hasil normalitas menggunakan metode Bartlet yaitu membandingkan varians terbesar dengan varians terkecil menurut Riduwan (2010:178) menyatakan: "Jika $F_{\text {hitung }} \geq F_{\text {tabel, }}$ berarti tidak Homogen danJika $F_{\text {hitung }} \leq$

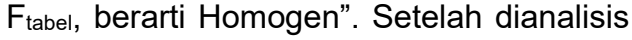
adapun hasil yang diperoleh sebagai berikut :

Tabel 6. Nilai Varian Sampel

\begin{tabular}{|c|c|c|}
\hline $\begin{array}{l}\text { Nilai Varians } \\
\text { Sampel }\end{array}$ & Pre-Test & $\begin{array}{l}\text { Post- } \\
\text { Test }\end{array}$ \\
\hline$S$ & 14,95 & 9,47 \\
\hline$N$ & 31 & 31 \\
\hline $\mathrm{F}_{\text {hitung }}=\frac{\text { Varians }}{\text { Varians }}$ & $\frac{\text { terbesar }}{\text { terkecil }}=$ & $\frac{14,95}{9,47}=$ \\
\hline
\end{tabular}

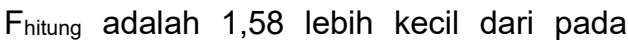
Ftabel yaitu 1,84 (dk pembilang $=31-1=$ 30 , dk penyebut $=31-1=30$, taraf signifikansi $5 \%$ ) maka dapat disimpulkan data tersebut adalah homogen dan dapat dilanjutkan untuk penghitungan uji pengaruh. Adapun hasil uji-t dan t tabel dapat diterangkan sebagai berikut:

Tabel 7. Data hasil uji-tdan tabel

\begin{tabular}{cccc}
\hline thitung & d.b. & ttabel & $\begin{array}{c}\text { Taraf } \\
\text { Signifikansi }\end{array}$ \\
\hline 8,32 & 30 & 2,04 & $5 \%$ \\
\hline \multicolumn{3}{c}{ Berdasarkan hasil analisis uji } \\
pengaruh diperoleh pada tabel di atas
\end{tabular}


menjelaskan thitung $(6,11)$ lebih besar dari tabel $(2,04)$ atau $\mathrm{Ha}$ diterima. Hasil tersebut menunjukkan bahwa ada pengaruh yang signifikan penggunaan alat peraga alam terhadap peningkatan hasil belajar fisika pada siswa kelas VIII di MTs Nurul Iman NW Kembang Kerang Lombok Tengah Tahun Pelajaran 2017/2018. Sedangkan untuk mengetahui derajat peningkatan hasil belajar siswa maka dilakukan perhitungan menggunakan n-gain. Hasilnya diperoleh sebagai berikut.

$$
\begin{gathered}
\text { Indeks gain }=\frac{\text { Skor posttest }- \text { Skor pretest }}{\text { Skormaksimum }- \text { Skor pretest }} \\
=\frac{60,56-53,67}{100-53,67}=0,149
\end{gathered}
$$

Hasil perhitungan tersebut menunjukkan bahwa penggunaan alat peraga alam terhadap peningkatan hasil belajar fisika pada siswa kelas VIII di MTs Nurul Iman NW Kembang Kerang Lombok Tengah Tahun Pelajaran 2017/2018 berada pada kategori rendah.

\section{SIMPULAN DAN SARAN}

Berdasarkan hasil penelitian, dapat disimpulkan bahwa terdapat pengaruh yang signifikan penggunaan alat peraga berbasis koil datar terhadap peningkatan hasil belajar fisika pada siswa kelas VIII di MTs Nurul Iman NW Kembang Kerang Lombok Tengah Tahun Pelajaran 2017/2018. Hal ini ditunjukkan dengan nilai thitung $(6,11)$ lebih besar dari tabel $(2,04)$.

Berdasarkan hasil penelitian yang telah dilakukan maka beberapa saran yang diajukan dari penelitian ini, antara:

1. Institusi (Sekolah) diharapkan hasil penelitian ini dapat dimanfaatkan dalam pengembangan kurikulum serta sebagai perbandingan dalam meningkatkan kualitas proses dan hasil pembelajaran sehingga pembelajaran berlangsung lebih efektif.

2. Bagi guru diharapkan agar terus menggunakan alat peraga alam pada materi getaran dan gelombang dan materi lainnya sehingga terjadi peningkatan hasil belajar fisika siswa.

3. Bagi siswa diharapkan mampu mengembangkan motivasi dan sungguhsungguh berpartisipasi aktif dalam mengikuti pembelajaran sehingga pengetahuan yang diperoleh benar-benar dipahami dan melekat dalam ingatan.

4. Bagi peneliti lain hasil penelitian ini diharapkan menjadi salah satu sumber informasi untuk mengadakan penelitian lebih lanjut dan sebagai bahan pertimbangan untuk perbaikan dan penyempurnaan penelitian yang akan dilaksanakan.

\section{DAFTAR PUSTAKA}

Arsyad, Azhar. 1995. Media Pendidikan. Jakarta: CV Rajawali.

Dirjen Dikdasmen, No.024/c/kep/R.1994

Dediknas. 2006. Kurikulum Pendidikan Dasar. Dirjen Dikdasmen: Jakarta.

Iskandar, Srini. 1997. Pendidikan IPA. Jakarta: Depdikbud
Julaiha, J., Islahudin, I., Sabaryati, J, (2017). Pengaruh Penggunaan Alat Peraga Berbantukan Kearifan Lokal Terhadap Hasil Belajar Siswa Kelas VII Di MTs Negeri 3 Mataram. ORBITA : Jurnal Kajian, Inovasi dan Aplikasi Pendidikan Fisika, 3(2), 1-7

Khanafiah, Siti. 2005. Metode Eksperimen Fisika. Diktat Kuliah. Semarang: Jurusan Fisika FMIPA UNNES.

Nurkancana, dkk. 1991. Evaluasi Hasil Belajar. Surabaya: Usaha Nasional.

1983. Evaluasi Hasil Belajar. Surabaya: Usaha Nasional.

Sugiono 2010. Metode Penelitian Kuantitatif Kualitatif dan R \& d. Bandung: CV Alfabeta.

2008. Metode Penelitian Kuantitatif Kualitatif dan R \& d. Bandung: CV Alfabeta.

Suparno, Paul. 2005. Miskonsepsi dan Perubahan Konsep dalam Pendidikan Fisika. Jakarta: PT. Grasindo. 